\title{
APPLICATION OF DISCUSSION LEARNING MODEL USING ARCS MOTIVATION STRATEGY TO IMPROVING STUDENT LEARNING OUTCOME
}

\author{
Alifia Fitranti \\ Mathematics Education, Faculty of Mathematics and Natural Sciences, Universitas Negeri Surabaya \\ Email: alifiafitranti16030174016@mhs.unesa.ac.id \\ Masriyah \\ Mathematics Education, Faculty of Mathematics and Natural Sciences, Universitas Negeri Surabaya \\ Email: masriyah@unesa.ac.id
}

\begin{abstract}
Several factors can cause a low student learning outcomes in mathematics. One of them is lack of motivation in learning so students are not enthusiastic in learning seen from students who tend to be embarrassed or afraid to ask questions, lack of responding to the teacher, and less responding to the teacher's explanation. Therefore, the importance of innovative learning and motivation can help students get the optimal learning process. This study aims, to describe the effectiveness of learning and improving student learning outcomes through discussion learning with ARCS motivation strategy about the surface area and volume of cube in $8^{\text {th }}$ grade of junior high school. This study use a quantitative descriptive study using one group pretest-post test study. The subject of this study are student of VIII-B in one of junior high school in Wonoayu with a total of 32 students. Data collection's methods are using tests (pretest and post test), questionnaires and observations. Data were analyzed descriptively quantitatively. To find out the increase in student learning outcomes in VIII-B class, the data were analyzed using n-gain. The results of this study include the ability of teachers to manage learning including good categories, students activities including active categories with an average percentage of $99.98 \%$, the response of students included in the good category with a percentage of $100 \%$, completeness student learning there are 28 students completed with a percentage of $87,50 \%$ and increased student learning outcomes including the medium category. Based on the results of the research data, the implication of the results of this study is the determination of appropriate learning models and strategies can be used to improve student learning outcomes. This is indicated by the gain score obtained by students belonging to the medium category. The use of the discussion learning model in this study is said to be effective because it has fulfilled 4 components, namely student learning activities, student responses, student learning completeness and increased student learning outcomes.
\end{abstract}

Keywords: discussion, ARCS motivation, result of learning

\section{INTRODUCTION}

Political and Economic Risk Consultant (PERC) in Sujarwo (2018) stated the results of a survey that from 12 countries in Asia ranked education in Indonesia ranked 12th. This caused the results of learning mathematics of Indonesian students currently at a level that has not been satisfactory. This is shown from the results presented by Organisation for Economic Cooperation and Development (OECD) (2018), the 2018 PISA results in mathematics get an average value of 379 out of 489 determined average scores and are ranked 72 of 78 countries. Student learning outcomes in mathematics are low, occurs due to various things. One of them according to Ardilla and Hartanto (2017) is the lack of student motivation towards mathematics. Based on the results of research conducted, Very low motivation of students towards lessons seen from students who tend to be shy or afraid to ask, not responding to the teacher, and not responding to the teacher's explanation. The teacher's role is very necessary to form a learning innovation by involving students in the learning process such as expressing opinions, discussing the solution of a problem.

One of innovative learning is discussion learning. According to Suryosubroto in Afandi (2013), the word discussion is the exchange of opinions about a problem or together looking for a solution of a problem by a group of people. According to Herijon (2014), the word discussion is the process of exchanging ideas to solve problems. In expressing an opinion there is a limitation of a problem that is the topic of conversation. It is noted that the discussion is not far off the mark and wide so that 
the results of the discussion can be drawn right and correct conclusions.

Discussion learning model is the steps of learning carried out in the learning environment by conducting discussions to resolve a problem given by the teacher. According to Lacen (1997) discussion as a learning method that can help students to organize and develop their own knowledge. Discussion can build students to be able to respond to each problem and relate it to everyday life. One of the lessons that can use the discussion learning model is mathematics because the subject matter delivered can be related to everyday problems so that student learning is more meaningful.

Discussion according to Wiyanto (2000), comes from the Latin language meaningful discussion or discussion. While in English the discussion comes from the word discussion which means discussion or discussion. In Indonesian, the word discussion means the exchange of opinions between two or more people about a topic of problems to achieve a certain goal. 3 elements of the discussion are 1) a conversation between two or more people, 2) the existence of a subject matter, 3) there is a goal to be achieved.

In addition to effective learning, good strategies are needed to achieve learning goals. One of them is the motivation given by the teacher to students. This is supported by Hamalik's statement (2014) that teachers' efforts to increase student motivation depend on the seriousness and attitude of responsibility in implementing learning so that learning can be carried out according to learning objectives. According to Uno (2007) motivation is one of the things that determines perseverance in learning so that later it will affect learning outcomes. Therefore, the learning process in the classroom needs the direction of a teacher who gives encouragement or motivation to students in the hope of achieving learning in accordance with what has been prepared.

Meanwhile, according to Sardiman (2007), the word motivation comes from the word motive which means encouragement. In English, motivation comes from the word to move. Motive is referred to as something that makes or causes someone to do something in order to achieve a certain goal.

Learning process in the classroom it is very necessary motivation so that in receiving the learning material students are excited so that learning outcomes and student achievement can increase. The statement is supported by a statement of Sardiman (2007) that student learning outcomes depend on the level of student motivation. Learning outcomes can be optimal if there is the right motivation. One of the external motivations is ARCS motivation stands for Attention, Relevance,
Confidence, and Satisfaction. Research related to ARCS motivation has been widely carried out, one of which is research conducted by Asiani et al (2017) that there is an increase in student learning outcomes after implementing ARCS motivation strategy. Other research related to ARCS motivation was conducted by Maidiyah and Fonda (2013) that te application of ARCS learning models to statistical material can influence student motivation and learning outcomes. The differences with this study are about the aspects that observed were not only learning outcomes and learning completeness but also the teacher's ability to manage learning and student's response toward the discussion learning model with ARCS motivation strategy.

ARCS motivation strategy is a strategy or way to motivate students to improve learning outcomes so that students are encouraged to do learning. ARCS motivation was developed by John. M Keller. Through the theory of expectation values that contain the value of the goals to be achieved and the expectation of the success of the strategy, Keller (2010) developed into 4 principles of motivational theory namely Attention, Relevance, Confidence, Satisfaction. This learning motivation emphasizes student attention to learning, associates learning with student experience, increases student confidence, and fosters student satisfaction in learning. So, the ARCS motivation strategy is that the teacher carries out learning in the classroom by motivating students by growing student interest and attention (attention), the linking the learning material with daily lives of students (relevance) that can foster a sense of self confidence in things to be resolved (confidence) so that a sense of satisfaction arises in them towards the process and learning outcomes (satisfaction).

Based on the description above, the purpose of this study is to describe the effectiveness of learning which consists of the management of teacher's ability to manage learning, student's activities, student's responses, completeness of student's learning and improvement of student's learning outcomes by applying discussion learning models with ARCS motivation strategy.

\section{METHOD}

This research uses descriptive research with a quantitative approach with a one group pretest post-test study design, which is a study that provides a test (pretest) first before giving treatment then giving a test (post-test) after giving treatment. Pretest and post-test is used to determine the comparison of student learning outcomes before and after treatment. The treatment given in this research is mathematics learning which uses discussion learning model with ARCS motivation 
strategy. Population in this research is a class VIII student at SMP Negeri 2 Wonoayu with sample selection using cluster sampling technique that is sampling in the form of groups in a population. In this study, several class groups in the population were taken randomly, the selected class was the sample in the study, namely class VIIIB.

The methods used in collecting data in this study include 1) Observation, to collect data related to the management of learning and student activities during learning. 2) Tests, to get data on student learning outcomes conducted before and after learning. The test is carried out objectively by being supervised by researchers and partner teachers so the test results can be obtained in accordance with the results of individual student abilities. 3) Questionnaire, which uses a closed questionnaire that is a questionnaire in the form of a statement along with the choice of answers. Questionnaire is used to get student's response data to the learning that has been done. Students fill out questionnaires after carrying out learning by using discussion learning models with ARCS motivation strategy.

The data that analyzed in this study are:

1. The teacher's ability to manage learning

Steps to analyzing data from the teacher's observation sheet during manage a learning are:

a. Give a score on each aspect of the teacher's ability to manage learning for each meeting

b. Convert scores (scores) to the ability of teachers to manage learning selected from the lowest score at all meetings with the following criteria.

Table 1 criteria of teacher's ability to manage learning

\begin{tabular}{|c|c|}
\hline Mode Score & Category \\
\hline Score $\leq 1,0$ & Less \\
\hline $2,0 \geq$ Score $>1,0$ & Enough \\
\hline $3,0 \geq$ Score $>2,0$ & Good \\
\hline $4,0 \geq$ Score $>3,0$ & Very Good \\
\hline
\end{tabular}

c. Calculate mode score of the teacher's ability to manage learning at each meeting.

d. Convert mode score of the teacher's ability to manage learning at each meeting chosen from the lowest score at all meetings.

2. The student's activities

After the learning process student activity data is analyzed by:

Percentage of student's activities= $\underline{\text { frequency of student'sactivity that appears }} \times 100 \%$ the number all of student'sactivities

(Masriyah, 2007)
According to Kirana (2013), if the average percentage of student activity during two meetings $\geq 80 \%$, students can be said to be active. Otherwise, if the average percentage of student activity during two meetings $<80 \%$ then the student is said to be passive.

3. The student's response

After the learning process, student's response data that have been obtained are analyzed with the following steps.

a. Determine the score on each answer choice using the likert scale

Table 2 Score category

\begin{tabular}{|c|c|c|}
\hline $\begin{array}{c}\text { Student's } \\
\text { score } \\
\text { category }\end{array}$ & $\begin{array}{c}\text { Favorable } \\
\text { test item } \\
\text { score }\end{array}$ & $\begin{array}{c}\text { Unavorable } \\
\text { test item } \\
\text { score }\end{array}$ \\
\hline SS & 4 & 1 \\
\hline S & 3 & 2 \\
\hline TS & 2 & 3 \\
\hline STS & 1 & 4 \\
\hline \multicolumn{2}{r}{ (Masriyah, 2018) }
\end{tabular}

Note :

STS: very disagree

TS: disagree

S: agree

SS: very agree

b. Count many students who choose the answer choices on each item questionnaire

c. Calculate student response scores on each student's choice of answers using a likert scale

d. Count the number of student response scores on each item statement

e. Calculate the percentage of students' response scores on each item in the answer choices using the formula:

$$
P=\frac{p}{p \max } \times 100 \%
$$

(Kirana, 2013)

Note:

P : Percentage of student's response score (SRS)

$p \quad:$ Total score for each statement

$p$ max: Maximum total scorefor each number choices

f. Describes the percentage obtained according to the categories in the following table.

Table 3 Persentage of student's response category

\begin{tabular}{|c|c|}
\hline Precentage & Category \\
\hline $25 \% \leq \mathrm{P}<45 \%$ & Less \\
\hline $45 \% \leq \mathrm{P}<65 \%$ & Enough \\
\hline $65 \leq \mathrm{P}<85 \%$ & Good \\
\hline $85 \leq \mathrm{P}<100 \%$ & Very good \\
\hline
\end{tabular}

If the percentage of students' response scores reaches good or very good assessment criteria, the student's response to learning is positive. 
Otherwise, if the student response score reaches the assessment criteria are not good or good enough, the student's response to learning is said to be negative.

4. The student's learning completeness

KKM determined by SMPN 2 Wonoayu in mathematics is 76. If the student learning outcomes more than or equal to the KKM value standard set by the school, students can be said to be complete. According to Fitryasari and Masriyah (2016), group completeness or class completeness is achieved if there are $\geq 75 \%$ of students who get a KKM grade. To find out classical completeness, obtained using the formula:

$$
\begin{aligned}
& \text { Percentage of student'slearning completeness } \\
& =\frac{\text { Estudents who'recomplete }}{\Sigma \text { all students }} \times 100 \%
\end{aligned}
$$

(Riduwan, 2010:13)

5. The improvement student learning outcomes

The normalized gain score is used to determine the increase in student learning outcomes. Test results that have been obtained are analyzed by comparing the difference in scorespost-test and pretest with the highest score obtained by students using the following formula.

$$
g=\frac{\text { Post test score }- \text { Pretest score }}{\text { Maximum score-Pretest score }}
$$

(Hake, 1999)

After obtaining normalized gain score then convert it in the following table

\begin{tabular}{|c|c|} 
Table 4 Criteria of $\mathbf{n}$-gain score \\
\hline Range & Criteria \\
\hline $0,3 \geq g>0$ & Low \\
\hline $0,7 \geq g>0,3$ & Medium \\
\hline $1,00 \geq g>0,7$ & High \\
\hline
\end{tabular}

(Hake, 1999)

\section{FINDING AND RESULT}

This study was conducted at VIII B class of SMPN 2 Wonoayu. In this study, teachers who teach VIII B class who had previously coordinated discussion learning with ARCS motivation strategy will be observed while conducting the learning process. The researcher and her partner observed the management of teacher's ability to manage learning and student's activities. Data was collected during 3 meetings, they are on March 19, 7 and 8 April 2020.

After the research has been conducted, data obtained by the teacher's ability to manage learning, student activity data, student's response data, student's learning completeness data and data of student's learning outcomes improvement in SMPN 2 Wonoayu. The result of research data are described as follows.

\section{The teacher's ability to manage learning}

Observation of learning management is conducted during the learning process by applying a discussion learning model with ARCS motivation strategy at the second and third meetings. The results of observations of learning management conducted are shown through the scores on the learning management observation sheet. Based on observations of the management of learning, the

\begin{tabular}{|c|c|c|c|c|}
\hline \multirow[b]{2}{*}{$\underset{\text { bum }}{\text { Num }}$} & \multirow{2}{*}{$\begin{array}{c}\text { The aspect } \\
\text { observed }\end{array}$} & \multicolumn{2}{|c|}{ Score } & \multirow{2}{*}{$\begin{array}{c}\text { Catego } \\
\text { ry }\end{array}$} \\
\hline & & P I & $\begin{array}{l}\mathbf{P} \\
\text { II } \\
\end{array}$ & \\
\hline & \multicolumn{4}{|c|}{ Introduction that includes: } \\
\hline & $\begin{array}{l}\text { a. Delivering the } \\
\text { learning } \\
\text { objectives }\end{array}$ & 3 & 3 & Baik \\
\hline & $\begin{array}{l}\text { b. Giving } \\
\text { apperception } \\
\text { questions and } \\
\text { stimulate } \\
\text { student's } \\
\text { curiosity } \\
\text { (Attention) }\end{array}$ & 3 & 2 & Cukup \\
\hline & $\begin{array}{l}\text { c. Linking } \\
\text { problems with } \\
\text { daily life } \\
\text { (Relevance) } \\
\end{array}$ & 3 & 3 & Good \\
\hline & $\begin{array}{l}\text { d. Explaining the } \\
\text { discussion } \\
\text { rules } \\
\end{array}$ & 3 & 3 & Good \\
\hline \multirow{4}{*}{2} & \multicolumn{4}{|c|}{ Core activities that includes: } \\
\hline & $\begin{array}{l}\text { a. Delivering the } \\
\text { problem }\end{array}$ & 3 & 3 & Good \\
\hline & $\begin{array}{l}\text { b. Observing } \\
\text { student } \\
\text { interactions } \\
\text { each group }\end{array}$ & 2 & 2 & Enough \\
\hline & $\begin{array}{ll}\text { c. } & \text { Asking } \\
\text { student's } & \\
\text { ideas in } \\
\text { solving } \\
\text { problems } \\
\text { (Confidence) } \\
\end{array}$ & 2 & 1 & Lack \\
\hline 3. & \multicolumn{4}{|c|}{ Closing activities that includes: } \\
\hline & $\begin{array}{l}\text { a. Summarizing } \\
\text { the results of } \\
\text { the } \\
\text { discussion }\end{array}$ & 3 & 3 & Good \\
\hline & $\begin{array}{ll}\text { b. } & \text { Providing } \\
\text { corrective } \\
\text { feedback }\end{array}$ & 3 & 3 & Good \\
\hline
\end{tabular}
results obtained from each meeting are as follows.

Table 5 Data of learning management's observation 


\begin{tabular}{|c|c|c|c|c|}
\hline \multirow[b]{2}{*}{$\underset{\text { b }}{\text { Num }}$} & \multirow[b]{2}{*}{$\begin{array}{c}\text { The aspect } \\
\text { observed }\end{array}$} & \multicolumn{2}{|c|}{ Score } & \multirow[b]{2}{*}{$\begin{array}{c}\text { Catego } \\
\text { ry }\end{array}$} \\
\hline & & $\begin{array}{l}\mathbf{P} \\
\mathbf{1}\end{array}$ & $\begin{array}{c}\text { PI } \\
\text { I }\end{array}$ & \\
\hline & $\begin{array}{l}\text { c. Giving praise } \\
\text { and prizes to } \\
\text { groups who } \\
\text { present in } \\
\text { front of the } \\
\text { class } \\
\text { (Satisfaction) }\end{array}$ & 2 & 2 & Enough \\
\hline \multicolumn{2}{|c|}{ Mode of each meeting } & 3 & 3 & Good \\
\hline
\end{tabular}

Note : PI : The first meeting PII : The second meeting

Based on the table above, in the first and second meeting scores obtained assessment of learning management with the value of mode 3 with good categories. On the learning management observation sheet several aspects were observed, including intriduction activities, core activities, and closing activities that were adjusted to the Lesson Plan (RPP) that had been designed using discussion learning models with ARCS motivational strategies. Based on the results of observations on the ability of teachers to manage learning, teachers have been able to manage learning well indicated through the observation scores that are categorized as good in every aspect observed. The statement is in line with the results of a study conducted by Fitriani (2017) that the ability of teachers to manage learning well due to systematic planning such as preparing the Lesson Plan (RPP) so that it matches the expected goals. However, there is one aspect that gets a score of 1 namely the activity of asking students' ideas in solving problems. Although the planning process has been conducted maximally and as well as possible, it happens due to unstable connections that hinder the learning process. This is not in accordance with the statement on the results of research conducted by Sumarni (2012) that the ability of teachers to manage learning can be increased due to the planning and implementation of the lesson plans that have been prepared. there is one aspect that gets a score of 1 namely the activity of asking student's ideas in solving problems. Although the planning process has been conducted optimally and as well as possible, it happens due to unstable connections that hinder the learning process. This is not in accordance with the statement on the results of research conducted by Sumarni (2012) that the ability of teachers to manage learning can be increased due to the planning and implementation process of the lesson plans that have been prepared.

\section{The student's activities}

Observation of student activities is conducted during the learning process that applying the discussion learning model to the ARCS motivation strategy at the second and third meetings. Observations were made on one group (6 students) by one observer, a research partner. The results of observations of student activities conducted are shown through the scores on the observation sheet of student activities. Based on observations that have been made, data obtained from observations of student activities at each meeting are as follows.

Table 6 Data of student's activities

\begin{tabular}{|c|l|c|c|c|}
\hline $\begin{array}{c}\text { Nu } \\
\text { m } \\
\text { be } \\
\mathbf{r}\end{array}$ & Student's activities & P1 & P2 & $\begin{array}{c}\text { Aver } \\
\text { age }\end{array}$ \\
\cline { 2 - 4 } 1. & $\begin{array}{l}\text { Paying attention to } \\
\text { the presentation of } \\
\text { powerpoint by the } \\
\text { teacher (Attention) }\end{array}$ & $\begin{array}{c}23,0 \\
7 \%\end{array}$ & $\begin{array}{c}21,6 \\
8 \%\end{array}$ & $\begin{array}{c}22,38 \\
\%\end{array}$ \\
\hline 2. & $\begin{array}{l}\text { Answering teacher } \\
\text { questions about } \\
\text { material related to } \\
\text { daily life (Relevance) }\end{array}$ & $\begin{array}{c}15,3 \\
8 \%\end{array}$ & $\begin{array}{c}14,4 \\
5 \%\end{array}$ & $\begin{array}{c}14,92 \\
\%\end{array}$ \\
\hline 3. & $\begin{array}{l}\text { Working on Student } \\
\text { Activity Sheets } \\
\text { (LKPD) }\end{array}$ & $\begin{array}{c}23,0 \\
7 \%\end{array}$ & $\begin{array}{c}21,6 \\
8 \%\end{array}$ & $\begin{array}{c}22,38 \\
\%\end{array}$ \\
\hline 4. & $\begin{array}{l}\text { Holding a discussions } \\
\text { with friends as a } \\
\text { group }\end{array}$ & $\begin{array}{c}23,0 \\
7 \%\end{array}$ & $\begin{array}{c}21,6 \\
8 \%\end{array}$ & $\begin{array}{c}22,38 \\
\%\end{array}$ \\
\hline 5. & $\begin{array}{l}\text { Presenting the results } \\
\text { of the discussion } \\
\text { (Confidence) }\end{array}$ & 00,0 \\
\hline 6. & $\begin{array}{l}\text { Responding to the } \\
\text { results of other group } \\
\text { presentations }\end{array}$ & $\begin{array}{c}2,40 \\
\%\end{array}$ & $\begin{array}{c}1,20 \\
\%\end{array}$ \\
\hline 7. & $\begin{array}{l}\text { Providing opinions } \\
\text { about learning that } \\
\text { has been done } \\
\text { (Satisfaction) }\end{array}$ & $\begin{array}{c}15 \% \\
8 \%\end{array}$ & $\begin{array}{c}14,4 \\
5 \%\end{array}$ & $\begin{array}{c}\% \\
\%\end{array}$ \\
\hline
\end{tabular}

Note : P1 : The first meeting P2 : The second meeting

All statements in the observation sheet of student activities are in accordance with the statement of Paul B. Diedrich in Sardiman (2007) that there are several types of student activities that are classified as follows: 1) Visual activities: reading, doing something, 2) Oral activities: opinion in discussions, asking questions , 3) writing activities: writing assignments, copying, 4) listening activities: listening to a presentation friend. Based on observations of student activity at all meetings, an average of $99.98 \%$ of all student activities in learning was obtained and said to be active. Students are said to be active if the 
percentage of all student activities reaches more than $80 \%$.

While the results of research conducted by Damayanti et al (2013) states that discussion learning can increase student activity in expressing opinions about the results of the discussion. But the statement is not in line with the results of this study because the learning process in this study was conducted online. Therefore student presentation activities are less than optimal and students do not focus on learning material.

\section{The student's response}

Student's responses toward a learning are student's responses to the implementation of discussion learning models with ARCS motivation strategy on the surface area and volume of the cube. The student response questionnaire consisted of favorable (positive) statements in statements $1,4,6,7$ and unfavorable (negative) statements in statements $2,3,5,8$. Students fill in the student response questionnaire after conducting a learning as much as two meetings. Based on the student response questionnaire in the appendix, the following results were obtained.

Table 7 Data of student's response

\begin{tabular}{|c|c|c|c|c|}
\hline $\begin{array}{c}\mathrm{Nu} \\
\mathrm{mb} \\
\mathrm{er}\end{array}$ & Statement & $\begin{array}{c}\text { Tota } \\
\text { l } \\
\text { scor } \\
\text { e }\end{array}$ & & $\begin{array}{c}\text { Categor } \\
\mathbf{y}\end{array}$ \\
\hline 1. & $\begin{array}{l}\text { Students feel } \\
\text { easy to } \\
\text { understand after } \\
\text { joining } \\
\text { mathematics a } \\
\text { learning about } \\
\text { surface and } \\
\text { volume of the } \\
\text { cube. }\end{array}$ & 101 & $\begin{array}{c}78,9 \\
0 \%\end{array}$ & Good \\
\hline 2. & $\begin{array}{l}\text { Students feel } \\
\text { comfortable with } \\
\text { the learning } \\
\text { atmosphere in the } \\
\text { classroom when } \\
\text { learning } \\
\text { mathematics } \\
\text { about surface } \\
\text { area and volume } \\
\text { of the cube. }\end{array}$ & 12 & $\begin{array}{l}75,7 \\
8 \%\end{array}$ & Good \\
\hline 3. & $\begin{array}{l}\text { Students feel } \\
\text { enjoy the } \\
\text { discussion during } \\
\text { learning about } \\
\text { surface area and }\end{array}$ & 101 & $\begin{array}{c}78,9 \\
0 \%\end{array}$ & Good \\
\hline
\end{tabular}

\begin{tabular}{|c|c|c|c|c|}
\hline $\begin{array}{c}\mathrm{Nu} \\
\mathrm{mb} \\
\mathrm{er}\end{array}$ & Statement & $\begin{array}{l}\text { Tota } \\
\text { l } \\
\text { scor } \\
\text { e }\end{array}$ & $\%$ & $\begin{array}{c}\text { Categor } \\
\mathbf{y}\end{array}$ \\
\hline & $\begin{array}{l}\text { volume of the } \\
\text { cube }\end{array}$ & & & \\
\hline 4. & \begin{tabular}{l}
\multicolumn{2}{l}{ Discussion } \\
learning makes \\
students more \\
confident.
\end{tabular} & 96 & $75 \%$ & Good \\
\hline 5. & $\begin{array}{l}\text { Students do not } \\
\text { find difficulties } \\
\text { in learning } \\
\text { mathematics } \\
\text { about surface } \\
\text { area and volume } \\
\text { of the cube in the } \\
\text { classroom. }\end{array}$ & 88 & $\begin{array}{c}68,7 \\
5 \%\end{array}$ & Good \\
\hline 6. & $\begin{array}{l}\text { Students feel that } \\
\text { discussion } \\
\text { learning about } \\
\text { surface area and } \\
\text { volume of a cube } \\
\text { is useful for daily } \\
\text { life. }\end{array}$ & 110 & $\begin{array}{c}85,9 \\
3 \%\end{array}$ & $\begin{array}{l}\text { Very } \\
\text { good }\end{array}$ \\
\hline 7. & $\begin{array}{l}\text { Students feel the } \\
\text { problems in } \\
\text { learning } \\
\text { discussion are } \\
\text { presented } \\
\text { interestingly. }\end{array}$ & 95 & $\begin{array}{c}74,2 \\
1 \%\end{array}$ & Good \\
\hline 8 & $\begin{array}{l}\text { Students are } \\
\text { satisfied with the } \\
\text { discussion about } \\
\text { surface area and } \\
\text { volume of the } \\
\text { cube. }\end{array}$ & 99 & $\begin{array}{c}77,3 \\
4 \%\end{array}$ & Good \\
\hline
\end{tabular}

According to the data in the table above, it can be seen that all items in the questionnaire are included in both good and very good categories therefore student's responses to learning applying discussion learning models with ARCS motivation strategies can be said to be positive with a percentage of $100 \%$. These results are in line with the results of research conducted by Pono (2012) that students' responses to discussion learning get a positive response with a percentage of $77 \%$.

4. The student's learning completeness

In accordance with the KKM standards set by the school, if the learning outcomes obtained by students are less than 76, students are said to be incomplete. Otherwise, if it exceed the KKM standard, students are said to be complete. Data of student's learning completeness in this study are student's learning 
completeness after conducting the post test as in the following table.

Table 8 Data of student's learning completeness

\begin{tabular}{|c|c|c|}
\hline Student & Score & Category \\
\hline 1 & 85 & Complete \\
\hline 2 & 100 & Complete \\
\hline 3 & 90 & Complete \\
\hline 4 & 72 & Incomplete \\
\hline 5 & 100 & Complete \\
\hline 6 & 100 & Complete \\
\hline 7 & 100 & Complete \\
\hline 8 & 100 & Complete \\
\hline 9 & 100 & Complete \\
\hline 10 & 75 & Incomplete \\
\hline 11 & 90 & Complete \\
\hline 12 & 74 & Incomplete \\
\hline 13 & 100 & Complete \\
\hline 14 & 76 & Complete \\
\hline 15 & 90 & Complete \\
\hline 16 & 80 & Complete \\
\hline 17 & 90 & Complete \\
\hline 18 & 88 & Complete \\
\hline 19 & 100 & Complete \\
\hline 20 & 80 & Complete \\
\hline 21 & 88 & Complete \\
\hline 22 & 100 & Complete \\
\hline 23 & 100 & Complete \\
\hline 24 & 90 & Complete \\
\hline 25 & 90 & Complete \\
\hline 26 & 91 & Complete \\
\hline 27 & 100 & Complete \\
\hline 28 & 100 & Complete \\
\hline 29 & 90 & Complete \\
\hline 30 & 72 & Incomplete \\
\hline 31 & 80 & Complete \\
\hline 32 & 100 & Complete \\
\hline
\end{tabular}

Based on the table above, student's learning completeness after conducting discussion learning with ARCS motivation strategy obtained a percentage of $87.5 \%$. These results are consistent with the results of research conducted by Ermi (2015) that the application of the discussion learning model can improve student learning completeness that can be seen from the results in the pre-study percentage of students who completed only $25.71 \%$ and $74.29 \%$ incomplete. Meanwhile, after learning completeness learning students get a percentage of $100 \%$ and the percentage of students who do not complete $0 \%$. This shows that all students have finished after conducting learning discussions.

In addition, student's learning completeness in this study can be said to be complete with a percentage $87,50 \%$ according to research of Suminah (2013) that student's learning completeness when students in the class have finished learning at least $75 \%$.

5. The improvement student learning outcomes

The improvement student learning outcomes obtained from gain score between pretest and post test. Based on the data analysis that has been done on pretest and post test score, we obtained a data of improvement student learning outcomes as follows.

Table 9 Data of improvement student learning outcomes

\begin{tabular}{|c|c|c|c|c|}
\hline \multirow{2}{*}{ Student } & \multicolumn{2}{|c|}{ SCORE } & \multirow{2}{*}{ N- } & Category \\
\cline { 2 - 4 } & PRETEST & $\begin{array}{c}\text { POST } \\
\text { TEST }\end{array}$ & GAIN & \\
\hline 1 & 69 & 85 & 0,5 & Medium \\
\hline 2 & 80 & 100 & 1 & High \\
\hline 3 & 68 & 90 & 0,7 & Medium \\
\hline 4 & 60 & 72 & 0,3 & Low \\
\hline 5 & 84 & 100 & 1 & High \\
\hline 6 & 96 & 100 & 1 & High \\
\hline 7 & 95 & 100 & 1 & High \\
\hline 8 & 78 & 100 & 1 & High \\
\hline 9 & 80 & 100 & 1 & High \\
\hline 10 & 65 & 75 & 0,3 & Low \\
\hline 11 & 80 & 90 & 0,5 & Medium \\
\hline 12 & 46 & 74 & 0,5 & Medium \\
\hline 13 & 84 & 100 & 1 & High \\
\hline 14 & 52 & 76 & 0,5 & Medium \\
\hline 15 & 84 & 90 & 0,4 & Medium \\
\hline 16 & 70 & 80 & 0,4 & Medium \\
\hline 17 & 52 & 90 & 0,8 & High \\
\hline 18 & 74 & 88 & 0,5 & Medium \\
\hline 19 & 95 & 100 & 1 & High \\
\hline 20 & 70 & 80 & 0,4 & Medium \\
\hline 21 & 54 & 88 & 0,7 & Medium \\
\hline 22 & 92 & 100 & 1 & High \\
\hline 23 & 82 & 100 & 1 & High \\
\hline 24 & 61 & 90 & 0,7 & Medium \\
\hline
\end{tabular}




\begin{tabular}{|c|c|c|c|c|}
\hline \multirow{2}{*}{ Student } & \multicolumn{2}{|c|}{ SCORE } & \multirow{2}{*}{$\begin{array}{c}\text { N- } \\
\text { Category }\end{array}$} \\
\cline { 2 - 5 } & PRETEST & $\begin{array}{c}\text { POST } \\
\text { TEST }\end{array}$ & & \\
\hline 25 & 84 & 90 & 0,4 & Medium \\
\hline 26 & 77 & 91 & 0,6 & Medium \\
\hline 27 & 80 & 100 & 1 & High \\
\hline 28 & 84 & 100 & 1 & High \\
\hline 29 & 73 & 90 & 0,6 & Medium \\
\hline 30 & 63 & 72 & 0,3 & Low \\
\hline 31 & 65 & 80 & 0,4 & Medium \\
\hline 32 & 74 & 100 & 1 & High \\
\hline Average & 74 & 90 & 0,6 & Medium \\
\hline
\end{tabular}

motivation strategy about surface area and volume of cube in students of VIII-B SMPN 2 Wonoayu including a active category with an average percentage of $99,98 \%$.

3. The student's response of VIII- B SMPN 2 Wonoayu toward a learning that applying discussion learning model using ARCS motivation strategy about surface area and volume of cube including a positive category with a percentage of $100 \%$.

4. The student's learning completeness that applying discussion learning model using ARCS motivation strategy about surface area and volume of cube in students of VIII-B SMPN 2 Wonoayu there are 28 students completed with a percentage $87,50 \%$.

Based on the table above, the average of gain score that obtained in the class included medium category with a percentage of $50 \%$. So that, the application of discussion learning models with ARCS motivation strategy can improve student's learning outcomes. That statement is according to research of Setyo (2018) that one of the goals to achieve learning is to improve learning outcomes to get a medium category.

In addition, other research also state that the discussion learning model can improve student's learning outcomes. It is a research by Ermi (2015) states that discussion learning can improve student's learning outcomes, it's shown by a higher percentage of student's completeness then a percentage of student's completeness before conducting a discussion learning and also research by Saadah (2017) states that applying discussion learning model can improve student's learning outcomes. It's shown by the percentage before applying discussion learning the average of student's completeness is $44,45 \%$ while after applying discussion learning the average of student's completeness is $100 \%$.

\section{CLOSURE}

\section{Conclusion}

Based on the result data, we can say that discussion learning model using ARCS motivation strategy is effective to teach about the surface area and volume of cube. It's showed by several things as follows.

1. The ability of teacher to manage leaning that applying discussion learning model using ARCS motivation strategy about surface area and volume of cube in students of VIII-B SMPN 2 Wonoayu including a good category.

2. The student's activities during learning process that applying discussion learning model using ARCS

\section{REFERENCES}

Afandi, dkk. 2013. Model Dan Metode Pembelajaran Di Sekolah. Semarang: UNISSULA Press

Ardilla, Ayu dan Suryo Hartanto. 2017. "Faktor Yang Mempengaruhi Rendahnya Hasil Belajar Matematika Siswa MTS Iskandar Muda Batam”. Phytagoras, 6(2): 175-186

Asiani, Ani. Hariani dan Jonet Ariyanto. "Penerapan Model Attention, Relevance, Confidence, And Satisfaction (Arcs) Untuk Meningkatkan Motivasi Dan Hasil Belajar Siswa Kelas X Pemasaran 1 Smk Negeri 1 Surakarta". BISE : Jurnal Pendidikan Bisnis dan Ekonomi : 111

Damayanti, Febti, Sudarmanto, Gunawan dan Teddy Rusman. 2013. "Penerapan model pembelajaran diskusi kelompok dengan menggunakan media handout untuk 
meingkatkan aktivitas dan kreativitas”. Jurnal Studi Sosial Volume 1 no. 4

Ermi, Netti. 2015. "Penggunaan Metode Diskusi untuk Meningkatkan Hasil Belajar Materi Perubahan Sosial pada Siswa Kelas XII SMA Negeri 4 Pekanbaru". Jurnal SOROT Volume 10 nomor $2: 155-168$

Fitriani, cut.dkk. 2017. "Kompetensi Profesional Guru Dalam Pengelolaan Pembelajaran Di Mts Muhammadiyah Banda Aceh". Jurnal Magister Administrasi Pendidikan Pascasarjana Universitas Syiah Kuala. Volume 5, no. 2: 88-95

Fitryasari, Lenny dan Masriyah. 2016. "Penerapan model pembelajaran pengajuan soal (problem posing) pada materi volume kubus dan balok di kelas VIII SMP Negeri 1 Krian”. Jurnal Ilmiah Pendidikan Matematika MATHEdunesa. Volume 2 no. 5 : 64 - 72

Hake, R. 1999. Analyzing Change/ Gain Score. Indiana: Indiana University

Hamalik, Oemar. 2016. Proses Belajar Mengajar.Jakarta: PT. Bumi Aksara

Keller, John.M. 2010. Motivational Design for Learning and Performance: The ARCS Model Approach (Online) (https://www.springer.com/gp/book/9781441 912497) diakses 29 November 2018

Kirana, Krisna. 2013. Penerapan Model Pembelajaran Kooperatif Tipe Murder Pada Materi Persamaan Garis Lurus Di Kelas VIII SMP Muhammadiyah 5 Surabaya

Lacen, Bruce E. 1997. Conceptions of Discussion as Method and Outcome.(Online) (https: /files.eric.ed.gov) diakses pada 3 Mei 2019

Maidiyah, Erni. 2013. "Penerapan Model Pembelajaran ARCS Pada Materi Statistika Di Kelas XI SMA Negeri RSBI Banda Aceh". Jurnal Peluang Volume 1 No. $2: 12-21$

Masriyah. 2007. Modul 9 Penyusunan Non Tes. Surabaya: Unesa University Press

Masriyah. 2018. Asesmen Proses Dan Hasil Belajar. Surabaya : UNESA University Press

OECD. 2018. PISA 2018 Results (Online) (http://www.oecd.org/) diakses pada 6 April 2020

Pono, Nasihudin. 2012. Pengaruh pembelajaran menggunakan metode diskusi kelompok terhadap prestasi belajar siswa pada pokok bahasan geometri dimensi tiga di MAN Kalimukti Kec. Pabedilan Kab. Cirebon (Online) (http://syekhnurjati.ac.id/) diakses pada tanggal 1 mei 2020

Riduwan. 2010. Skala Pengukuran Variabel-variabel Penelitian. Bandung: Alfabeta

Saadah. 2017. "Penerapan Metode Diskusi Untuk Meningkatkan Hasil Belajar Matematika Pada Materi Menggunakan Pecahan Dalam Pemecahan Masalah Siswa Kelas V Sdn 003 Tembilahan Kota Kecamatan Tembilahan". Jurnal Primary Program Studi Pendidikan Guru Sekolah Dasar Fakultas Keguruan dan Ilmu Pendidikan Universitas Riau Vol. 6 no. 2: $539-545$

Sardiman. 2007. Interaksi dan Motivasi Belajar Mengajar. Jakarta: Raja Grafindo Persada

Setyo, Arie Anang. 2018. "Keefektifan Pembelajaran Kooperatif Tipe STAD Integrasi Teori Belajar Van Hiele Pada Materi Geomateri di Kelas V Sekolah Dasar". Qalam: Jurnal Ilmu Kependidikan Vol. 6 no. 1 : 1-11

Simbolon, Herijon, Idris, Irsal dan Effie Efrida Muchlis. 2014. Penerapan Metode Pembelajaran Diskusi Kelas dan Open-Ended Questions Untuk Meningkatkan Hasil Belajar Siswa Kelas VIII SMPN/2 Bengkulu (Online) (http://repository.unib.ac.id/) diakses pada 6 April 2020

Sujarwo. 2018. Pendidikan di Indonesia Memprihatinkan (Online) ((http://staffnew.uny.ac.id/) diakses pada 24 November 2019

Sumarni, Aidar. 2012. Meningkatkan Kemampuan Guru Dalam Pelaksanaan Pembelajaran Pendidikan Agama Islam Melalui Lesson Study Di Sd Negeri Bandar Setia (Online) (http://repository.uinsu.ac.id/) diakses pada tanggal 14 April 2020

Suminah. 2013. Peningkatan hasil belajar siswa dengan menerapkan metode diskusi tipe buzzgroup pada mata pelajaran IPS kelas IV siswa sekolah dasar (Online) (http://jurnalmahasiswa.unesa.ac.id/) diakses pada tanggal 1 mei 2020

Uno, B. Hamzah. 2007. Teori Motivasi \& Pengukurannya. Jakarta: Bumi Aksara

Wiyanto, Asul. 2000. Seri Terampil Diskusi. Jakarta: PT. Grasindo 

PENERAPAN MODEL PEMBELAJARAN DISKUSI...

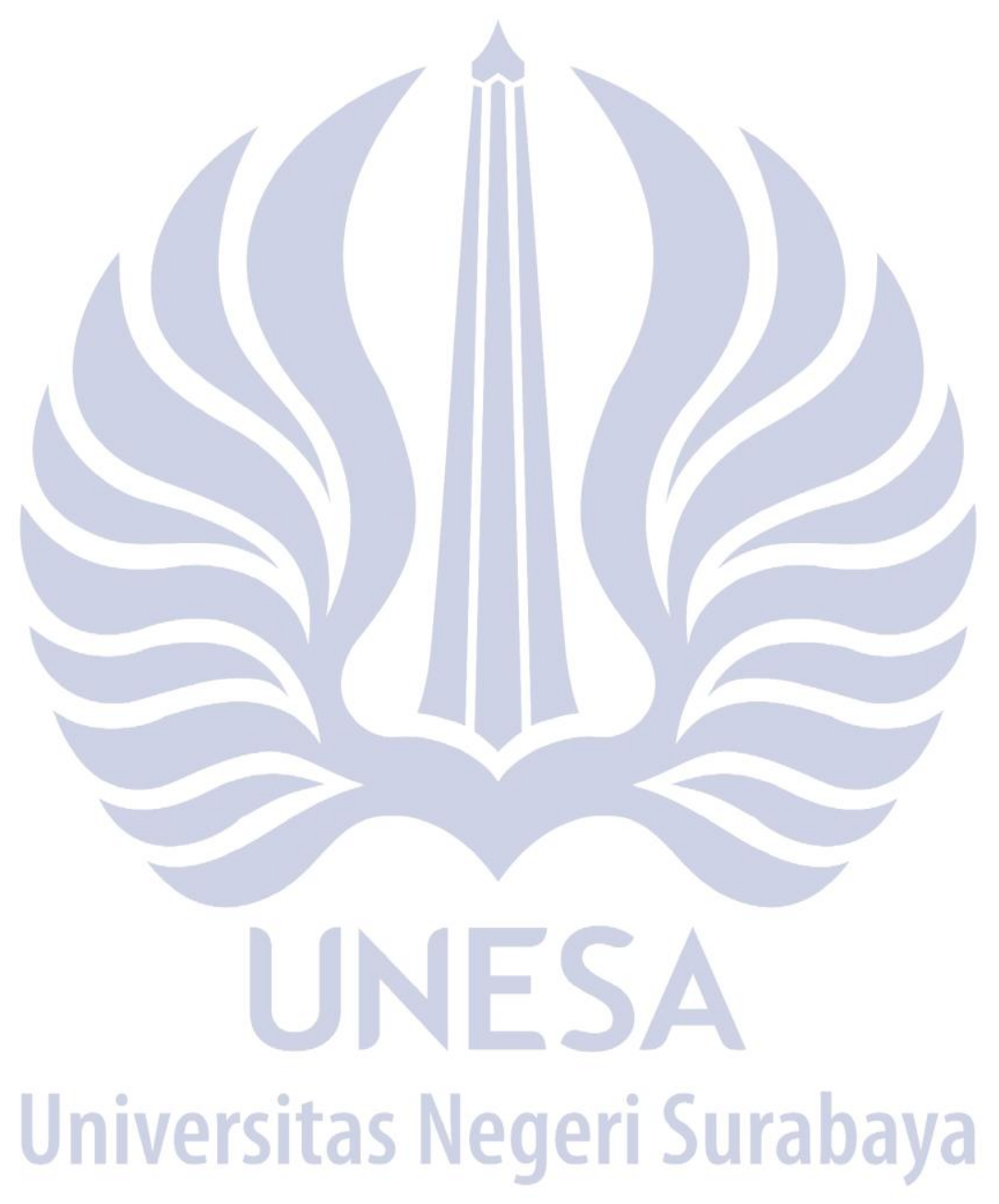

